\title{
The Effects of Packaging Variations Toward the Level of Bacteria's Contamination in
}

\section{Instant Uduk Rice}

\author{
Asrul Bahar, Dwi Kristiatuti Suwardiah \\ Department of Home Economic \\ Universitas Negeri Surabaya \\ Surabaya, Indonesia \\ asrulbahar@unesa.ac.id
}

\begin{abstract}
Food packaging has several functions such as to keep the food clean, to prevent contaminations by microorganisms, to protect the product from any physical and chemical harm. This research aimed to know the effects of packaging's materials variations toward the storage of the instant uduk rice, and the levels of panellists' preference toward the instant $u d u k$ rice's taste, scent, and colour. The result of the study from the laboratory test showed significantly that there we difference of the bacterial contamination toward the instant $u d u k$ rice which was packaged with aluminium foil and plastics. The packaging size was $1.2 \times 10^{2}$ for the plastics and $5.3 \times 10$ for aluminium foils. They were for eight weeks of food stores. The result of the organoleptic test showed that there were significant differences between aluminium foils and plastics packaging for the predilection of colour and aroma, with the value of 0.046 and 0.006 (less than 5\%). On the other hand, there was no significant difference for the taste with the value of 0.694 (more than 5\%), while for the predilection, in general, showed significant difference with the value of $\mathbf{0 . 0 4 9 6}$ (less than $5 \%$ ).
\end{abstract}

Keywords - instant uduk rice; packaging variation; storage; predilection level.

\section{INTRODUCTION}

In daily activities, food is one of the human's primary needs. As the technology development, food products have developed in the techniques of processing, preservation, packaging, and distribution. Related to those, the researcher needed to arrange a subsequent observation by observing packaging variations toward the storage of instant $u d u k$ rice. Codex Allimentarius Commission (CAC) has created Food Labelling Regulation that is about food storage determination in 1985. In Indonesia, regulations about food storage determination are in the Food Constitution number 7, 1996 and Government Regulations number 69, 1999. Seven types of food have to follow the regulation are fresh fruits and vegetables including unpeeled potatoes, beverages that contain $10 \%$ or more alcohol, food that is produced to be consumed immediately or not more than 24 hours after production, vinegar, salt, sugar, and candies. In addition, the basic ingredients of the candies sugar with additional flavour or sugar with additional colouring are also as the consideration of the food regulation. As the mentioned background, a subsequent observation has been generated about the produced instant $u d u k$ rice. The subsequent observation was focused on the products storage in two kinds of packaging, which were aluminium foil and plastics through a microbiological test. Beside the microbiological test, there is also food fondness test by panellist toward the instant $u d u k$ rice from both kinds of packaging.

The steps of making instant rice can be done by various ways; some of them are soaking the rice in a chemical solution, freezing the rice, and drying of the rice [1]. Basically, the starch that is soaked in cold water would absorb the water and it makes the starch expand. Despite that, the absorbed water volume was limited and only $26 \%$ from its previous volume. The starch needs to be soaked in a chemical solution to increase the water absorption. Based on the result of Box-Behnken technique of optimization by specifying the process responses as color, rehydration ratio and textural qualities of products, the optimal processing conditions for water-rice ratio (WRR), microwave power level (MWL) and hot air temperature (HAT) are 1.44.499.8 W and $89.990 \mathrm{C}$ respectively with $88 \%$ overall desirability. MWL find to be a remarkably key effect on all the process responses. The microscopic images of products illustrated that microwave drying at $595 \mathrm{~W}$ causes the puffing or volume expansion of the rice structure leading to greater porosity than microwave drying at $255 \mathrm{~W}$. The more porosity occurring at high MWL is expected to be the vital cause of preferable characteristics of instant brown rice [2]. Starch digestibility is determined by analyzing the amount of rapidly digestible starch (RDS), slowly digestible starch (SDS) and resistant starch (RS) in the instant rice. Cooking at $86 \mathrm{C}$ for 28 minutes in a 1.0 -fold volume of water significantly reduces RDS and increases SDS if it is compared to rice that cooked in a traditional electronic cooker. The combination of retrogradation and lowtemperature drying significantly reduce the RDS of instant rice after rehydration. A reduction in RDS was accompanied by an increase in SDS and RS in low-amylose japonica rice increase RS in low amylose rice, reduce SDS and increased $\mathrm{RS}$ in high-amylose rice. The optimizing cooking methods and retrogradation can reduce the starch digestibility of instant rice; this may help improve the quality of health [3] 
Food drying has two goals. The first goal is to preserve the food. Microorganisms that damage the food will not grow and survive in the environment with low water level. Besides, many enzymes, which cause a chemical change to food, will not work without water [4]. The second goal is to minimize the food distribution cost since dried food has lighter weight and smaller size. Drying is a complex operation that includes transient heat and mass movement, some processing speed, such as organoleptic or chemical transformation can cause the result of the quality change or mechanism of heat and mass movement. The possible organoleptic changes are shrivelling, clotting, crystallization, and glass transition. In some cases, there are possible on the chemical or biochemical changes that are wanted or are not that can cause the changes of colour, texture, scent, or other solid characteristics.

Food packaging that has widely spread out is aluminium foil and plastics. Aluminum foil is a metal that has several benefits such as mild, easy to form, tasteless, odourless, nonpoisonous, able to prevent air entrance, having good heat conductivity, and recyclable. This kind of packaging also has several disadvantages especially for the higher cost that compared with plastics [5]. Aluminum foil packaging is in form of solid and thin with $<0.15 \mathrm{~mm}$ thickness. The thickness determines the protection. It means that the gas and steam can permeate the foil if it is not thick enough. In 0.0375 $\mathrm{mm}$ thickness, the permeability of steam $=0$, which means the foil is not permeable to steam. Foil with $0.009 \mathrm{~mm}$ is commonly used for candies and milk, and foil with $0.05 \mathrm{~mm}$ thickness is used for multi-trip bottles. Aluminum foil has characters of hermetic, flexible, and light proof. Hence, it can be used in packaging for fatty food that is sensitive to the light [5].

Plastic is one of other choices besides aluminium foil. Plastic is highly used for human's needs such as for the need of household to industry [6]. As a food packaging, plastic is used to the food processor until it is ready to be consumed. Plastic is used as a packaging for food because the benefit of flexibility that can be suited in any form of food. Plastic is also light, not easily breakable, and transparent that make the product inside can be seen. It is also easy to label the packaging. Other benefits of plastic for packaging are produced in many colours, can be produced in big quantity, relatively cheap, and is available in various types. The disadvantages of plastics as a food packaging, for some kinds, are not heat resistant, easy to release dangerous migrants from monomers residual from polymers and durable to be biodegraded thus it potentially harms the environment. Lowdensity polyethylene is one of the most widely used packaging plastics. It is a member of the polyolefin family [7]. The safety of plastics can be seen from the written logo on the packaging that categorized as food safe, for food use, food grade. Generally, plastics should not be used to be the packaging of food that can be seen from the characteristics such as acid, fatty, oily, or hot condition [6]. The major advantage of flexible packaging is the economy. Flexible packaging makes the efficient use of both materials and space. The product ratio that delivered to the material package shows high and the use of cube is efficient. It means that the distribution of packaging only a few. Storage of unfilled packages engages in a very little space, especially for the stock web storage. Forming packages is generally rapid and in a simple way. All of this contributes to the lower cost [8].

The purpose of this research is to know the effects of packaging's materials variations toward the storage of the instant $u d u k$ rice, and the levels of panellists' preference toward the instant $u d u k$ rice's taste, scent, and colour.

\section{METHODS}

The research was experimental to know the effects of food packaging variations toward the instant $u d u k$ rice storage.The variations of food packagings were plastics and aluminium foil. Storage of instant $u d u k$ rice was observed weekly (once in seven days) for eight weeks (two months).

The data collected by observation and laboratory test method. Observation method was arranged by organoleptic test with 30 respondents. The observation is to know the fondness of colour, scent, taste, and texture of the instant $u d u k$ rice after it is packed in plastics and aluminium foil. While the laboratory test was done in Observation Center and Industry Consulate by the total microbe test using Plate Count Agar (PCA) medium after one week (seven days) of storage. The intervals of testing period $1-8$ weeks that was done each week. Then the instant $u d u k$ rice products were packed using plastics and aluminium foil.

The data analysis technique was measured by SPSS of 18.00 version of a computer program by using parametric analysis which is known as ANOVA test. The purpose is to know the effects of packaging types toward the panellist's fondness level of instant $u d u k$ rice including the taste, scent, colour, and general acceptance. After the organoleptic test, microbe test was done for seven days with the intervals of testing period $1-8$ weeks.

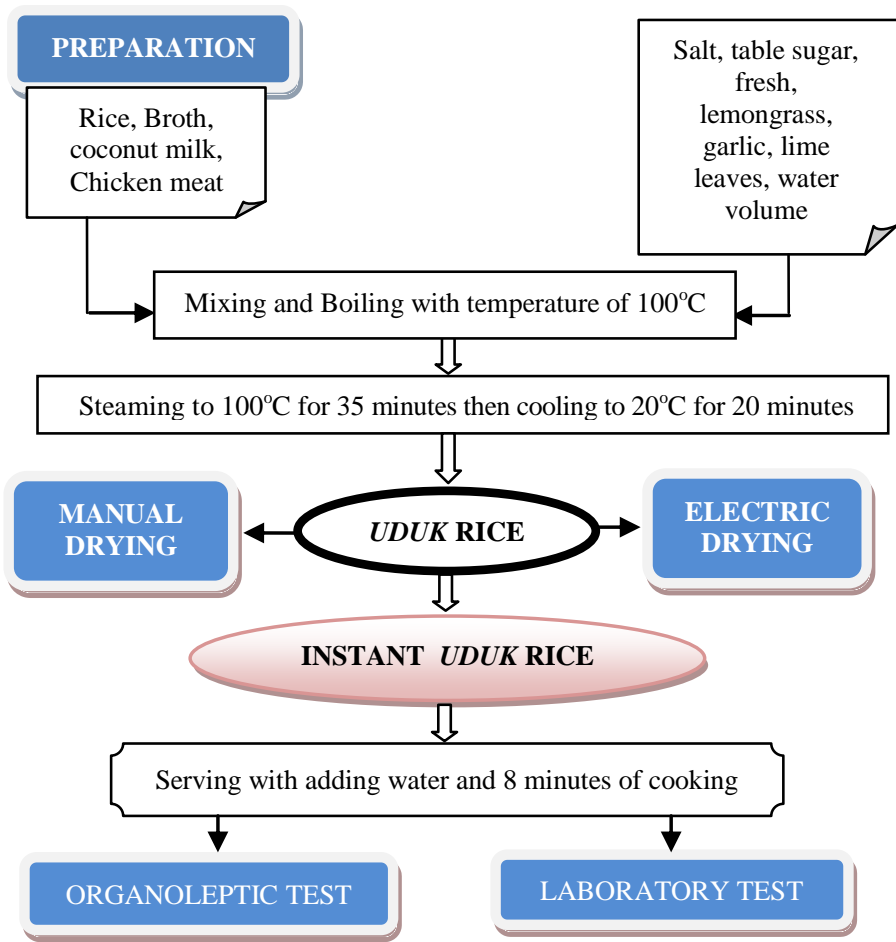

FFig. 1. Diagram of Instant $U d u k$ Rice Making 


\section{RESUlT AND DISCUSSION}

\section{A. Laboratory Test Result}

The data of bacteria's contamination based on the packaging show as follows:

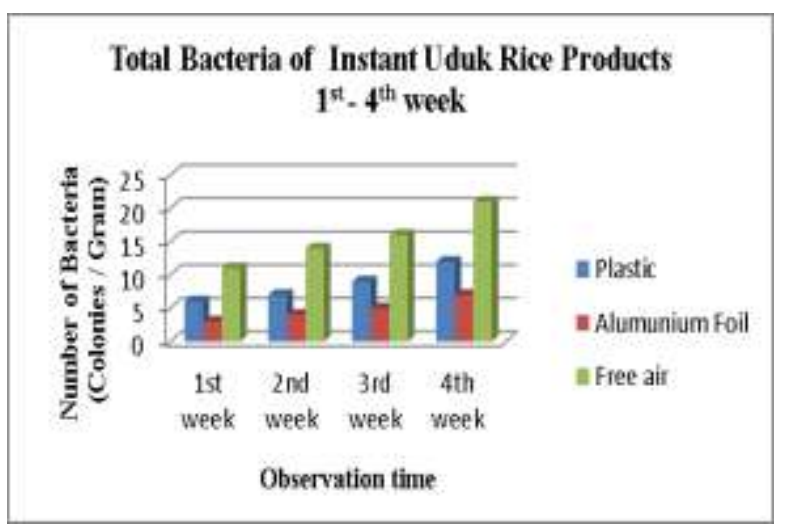

Fig. 2. Total of bacteria in instant $u d u k$ rice for four weeks

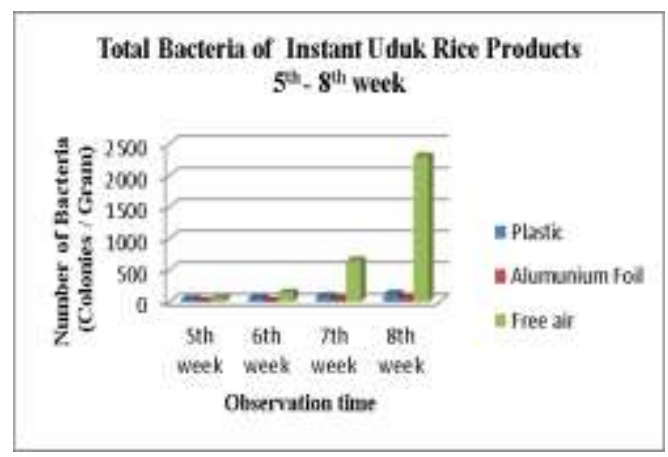

Fig. 3. Total of bacteria in instant $u d u k$ rice for two months

TABLE I. PERIOD AND AMOUNT OF BACTERIA INSIDE THE PACKAGE

\begin{tabular}{|c|c|c|c|}
\hline \multirow{2}{*}{ Period } & \multicolumn{3}{|c|}{ Packaging } \\
\cline { 2 - 4 } & Plastic & Aluminum Foil & Air \\
\hline $1^{\text {st }}$ Week & $0.6 \times 10$ & $0.3 \times 10$ & $1.1 \times 10$ \\
\hline $2^{\text {nd }}$ Week & $0.7 \times 10$ & $0.4 \times 10$ & $1.4 \times 10$ \\
\hline $3^{\text {rd }}$ Week & $0.9 \times 10$ & $0.5 \times 10$ & $1.6 \times 10$ \\
\hline $4^{\text {th }}$ Week & $1.2 \times 10$ & $0.7 \times 10$ & $2.1 \times 10$ \\
\hline $5^{\text {th }}$ Week & $3.2 \times 10$ & $0.9 \times 10$ & $4.6 \times 10$ \\
\hline $6^{\text {th }}$ Week & $5.8 \times 10$ & $1.2 \times 10$ & $1.4 \times 10^{2}$ \\
\hline $7^{\text {th }}$ Week & $8.1 \times 10$ & $3.5 \times 10$ & $6.5 \times 10^{2}$ \\
\hline $8^{\text {th }}$ Week & $1.2 \times 10^{2}$ & $5.3 \times 10$ & $2.3 \times 10^{3}$ \\
\hline
\end{tabular}

Source: Observation Laboratory and Industry Consulate (2014)

Based on the tables and graphics above, bacteria's contamination in instant $u d u k$ rice that treated by opened in the air and packed in aluminium foil and plastics for eight weeks. The result showed from the $1^{\text {st }}$ until the $8^{\text {th }}$ week, the lowest bacteria (colony/gram) was in aluminium foil and the highest was in the open air or no packaging.

On the first week, the bacteria total for the rice packed by plastic were $0.6 \times 10$, while the rice packed by aluminium foil was $0.3 \times 10$ of bacteria, and the rice in the open air was $1.1 \mathrm{x}$
10 of bacteria. On the second week, the bacteria total for the rice packed by plastic were $0.7 \times 10$, the rice packed by aluminium foil was $0.4 \times 10$, and the rice in the open air was $1.4 \times 10$.

On the third week, the bacteria total for the rice packed by plastic were $0.9 \times 10$, the bacteria's total for the rice packed by aluminium foil was $0.5 \times 10$, and the bacteria total for the rice in the open air were $1.6 \times 10$. On the fourth week, the bacteria total for the rice packed by plastic packaging were $1.2 \times 10$, the bacteria's total for the rice packed by aluminium foil was $0.7 \times 10$, and the bacteria total for the rice in the open air were $2.1 \times 10$.

On the fifth week, the bacteria total for the rice packed by plastic were $3.2 \times 10$, the bacteria total for the rice packed by aluminium foil were $0.9 \times 10$, and the bacteria total for the rice in the open air were $4.6 \times 10$. On the sixth week, the bacteria total for the rice packed by plastic were $5.8 \times 10$, the bacteria total for the rice packed by aluminium foil were $1.2 \times 10$, and the bacteria total for the rice in the open air were $1.4 \times 10^{2}$. On the seventh week, the bacteria total for the rice packed by plastic were $8.1 \times 10$, the bacteria total for the rice packed by aluminium foil were $3.5 \times 10$, and the bacteria total for the rice in the open air were $6.5 \times 10^{2}$. On the eighth week, the bacteria total for the rice packed by plastic were $1.2 \times 10^{2}$, the bacteria total for the rice packed by aluminium foil were $5.3 \mathrm{x}$ 10 , and the bacteria total for the rice in the open air were $2.3 \mathrm{x}$ $10^{3}$.

Based on the laboratory test result, the lowest bacteria (colony/gram) were contained in the instant $u d u k$ rice that was packaged with aluminium foil. Meanwhile, the highest bacteria (colony/gram) were contained in the instant $u d u k$ rice was in open-air/without packaging. Those were caused by aluminium foil's characteristics which were hermetic, flexible, light proof and gas prof. Thus, these characters were advantages to prevent the growth of microbes, and aluminium foil was better to be the packaging for fatty food that was sensitive toward the light. The plastic packaging had higher bacteria contamination compared to aluminium foil because it is transparent and allowed light to contaminate the food. The light was one of the factors that accelerated the growth of bacteria and fungi because the temperature inside the packaging would heat the water and because of the room temperature factors. Despite, the fact that plastics showed higher contamination, it is below the danger limitation that the food was still safe to eat because the limitation of the danger of bacterial contamination is more than $10^{3}$ [9].

\section{B. Organoleptic Characteristics}

An organoleptic test was arranged by inviting 30 expert respondents who were the lecturers from Home Economics Department. An organoleptic test was held by observing the instant $u d u k$ rice that was already packed using plastics and aluminium foil in two months. The result of the organoleptic test included the fondness toward colour, taste, scent, and general fondness toward the instant $u d u k$ rice. The result was as follows: 


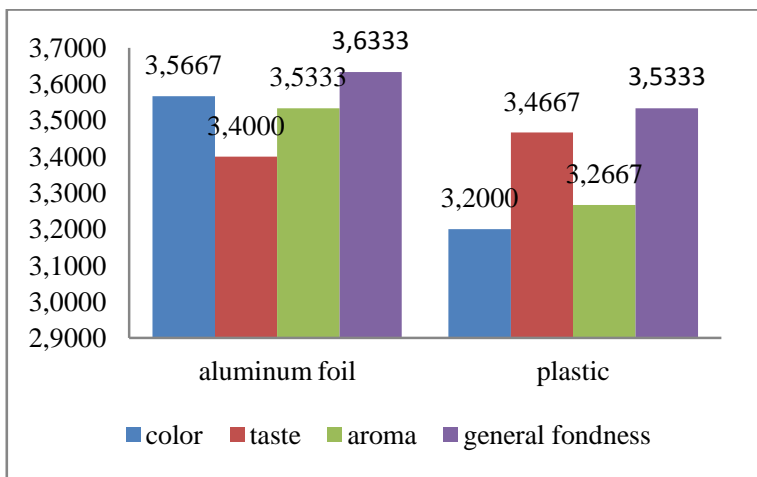

Fig. 4. Mean Value of Fondness Based on Packaging Kinds

According to the graphics, the mean values of fondness based on the packaging kinds for aluminium foil resulted in 3.5667 for the colour, 3.4000 for the taste, 3.5333 for the scent, and 3.6333 for general fondness. Meanwhile, the plastics package resulted in 3.2000 for the colour, 3.4667 for the taste, 3.2667 for the scent, and 3.5333 for general fondness.

\section{CONCLUSION}

Aluminum foil and plastics packaging resulted in genuine differences in bacteria's contamination for the food products. It was determined the product's storage. Aluminum foil and plastics packaging showed significant effects on the fondness level for colour, scent, and general fondness, while for the taste there was no significant effect.

\section{ACKNOWLEDGMENT}

Acknowledgments of the authors express for Directorate of Research and Community Service Ministry of Research and Technology of Higher Education Republic of Indonesia for financial support through Superior Research Programs of Higher Education 2017 and to Institute for Research and Community Service of Surabaya State University.

\section{REFERENCES}

[1] B.S. Luh, , R.L. Robert and C.F. Li. "Quick Cooking Rice". in Rice Production and Utilization, B.S. Luh, Eds. Westport. Connecticut: AVI Publ. Comp. Inc., 1980.

[2] Le, Tuan Quoc and Weerachet Jittanit. "Optimization of operating process parameters for instant brown rice production with microwavefollowed by convective hot air drying". Journal of Stored Products Research, vol. 61, pp. 1-8, 2015

[3] Hsu, Rachel Jui-cheng, Hong-Jhang Chen, Shin Lu, Wenchang Chiang. "Effects of cooking, retrogradation and drying on starch digestibility in instant rice making". Journal of Cereal Science vol. 65, pp. $154-161$, 2015 .

[4] C.J. Geankoplis. Transport Process and Unit Operations, 3rd ed., Singapore: Prentice Hall International, Inc., 1995.

[5] M. Astawan, Keunggulan Aluminium Foil \& Logam. http://portal.cbn.net.id/cbprtl/cybermed/detail.aspx? $\mathrm{x}=$ Nutrition \&y=cybe rshopping006/474. 2008.

[6] Dirjen Industri Kecil Menengah. 2007. Kemasan Flexibel. Jakarta: Departemen Perindustrian

[7] Selke, Susan E.M. and John D. Culter. "Major Plastics in Packaging". in Plastics Packaging (Third Edition), Science Direct, 2016, pp. 101-157.

[8] Selke, Susan E.M. and John D. Culter. "Flexible Packaging". in Plastics Packaging (Third Edition), Science Direct, 2016, pp. 257-266.

[9] Buckle, K.A, dkk (Penerjemah Hari Purnomo). Ilmu Pangan. Jakarta : UI- PRESS, 1987.

[10] Effendi, Samsoeri. Ensiklopedi Tumbuh-Tumbuhan. Surabaya: Karya Anda, 1993.

[11] Kristiastuti, Dwi. Modul Bahan Ajar Pengelolaan Makanan Nusantara. Surabaya: Unesa Press, 2012.

[12] Miles and A Michael Huberman. Qualitative Data Analysis. Beverly Hills: Sage Publications, 1984 